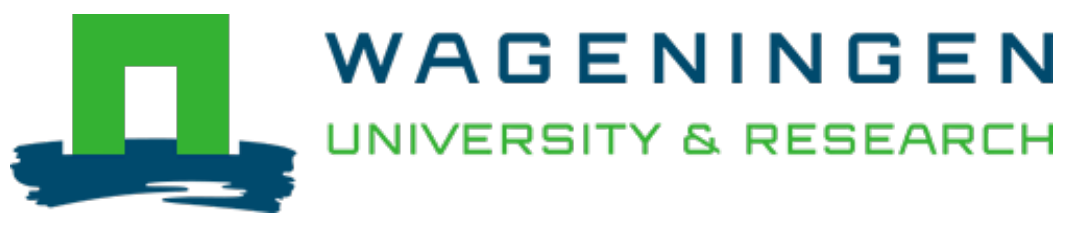

\title{
Effects of sodium reduction scenarios on fermentation and quality of sauerkraut
}

Food Science and Technology $=$ Lebensmittel-Wissenschaft und Technologie

Wolkers-Rooijackers, J.C.M.; Thomas, S.M.; Nout, M.J.R.

https://doi.org/10.1016/j.lwt.2013.07.002

This publication is made publicly available in the institutional repository of Wageningen University and Research, under the terms of article $25 \mathrm{fa}$ of the Dutch Copyright Act, also known as the Amendment Taverne. This has been done with explicit consent by the author.

Article $25 \mathrm{fa}$ states that the author of a short scientific work funded either wholly or partially by Dutch public funds is entitled to make that work publicly available for no consideration following a reasonable period of time after the work was first published, provided that clear reference is made to the source of the first publication of the work.

This publication is distributed under The Association of Universities in the Netherlands (VSNU) 'Article $25 \mathrm{fa}$ implementation' project. In this project research outputs of researchers employed by Dutch Universities that comply with the legal requirements of Article $25 \mathrm{fa}$ of the Dutch Copyright Act are distributed online and free of cost or other barriers in institutional repositories. Research outputs are distributed six months after their first online publication in the original published version and with proper attribution to the source of the original publication.

You are permitted to download and use the publication for personal purposes. All rights remain with the author(s) and / or copyright owner(s) of this work. Any use of the publication or parts of it other than authorised under article $25 \mathrm{fa}$ of the Dutch Copyright act is prohibited. Wageningen University \& Research and the author(s) of this publication shall not be held responsible or liable for any damages resulting from your (re)use of this publication.

For questions regarding the public availability of this publication please contact openscience.library@wur.nl 


\title{
Effects of sodium reduction scenarios on fermentation and quality of sauerkraut
}

\author{
J.C.M. Wolkers-Rooijackers, S.M. Thomas, M.J.R. Nout* \\ Laboratory of Food Microbiology, Wageningen University, P.O. Box 8129, 6700EV Wageningen, The Netherlands
}

\section{A R T I C L E I N F O}

\section{Article history:}

Received 9 February 2013

Received in revised form

15 June 2013

Accepted 4 July 2013

\section{Keywords:}

Sodium reduction

Microbial ecology

Cabbage texture

Sensory

Osmotic effect

\begin{abstract}
A B S T R A C T
Health authorities advocate the reduction of sodium intake because of its negative impact on health. The effect of sodium reduction on the natural fermentation in sauerkraut was investigated in terms of quality and safety. In addition to $15 \mathrm{~g} \mathrm{~kg}^{-1} \mathrm{NaCl}$ control [A], two alternative sodium reduction scenarios were tested: [B] salt reduction $\left(9 \mathrm{~g} \mathrm{~kg}^{-1} \mathrm{NaCl}\right)$, and [C] $40 \%$ partial sodium replacement $\left(9 \mathrm{~g} \mathrm{~kg}^{-1} \mathrm{NaCl}, 4.5 \mathrm{~g} \mathrm{~kg}^{-1}\right.$ $\mathrm{KCl}, 0.75 \mathrm{~g} \mathrm{~kg}^{-1} \mathrm{MgCl}_{2}$, and $\left.0.75 \mathrm{~g} \mathrm{~kg}^{-1} \mathrm{CaCl}_{2}\right)$. Microbiological safety was similarly assured in all samples, associated with low pH values (3.4-3.7) indicating an adequate lactic acid fermentation. PCR-DGGE and cloning revealed differences in microbial flora between treatments during first weeks of fermentation. Lactococcus lactis and Leuconostoc mesenteroides dominated $[\mathrm{A}],[\mathrm{B}]$ and $[\mathrm{C}]$, while $[\mathrm{C}]$ showed additional abundance of Lactobacillus paraplantarum and Lactobacillus curvatus. Treatment [B] did not meet industrial criteria for good quality; texture was too soft compared with $[A]$ and $[C]$. Sensory evaluation showed that both $[A]$ and $[C]$ were equally acceptable as judged by an industrial panel for aroma, taste and texture. Partially replacing sodium salt can successfully maintain high product quality, and thus offers a promising approach to substantially reduce sodium in sauerkraut fermentation.
\end{abstract}

(c) 2013 Elsevier Ltd. All rights reserved.

\section{Introduction}

Dietary sodium is associated with elevated blood pressure (Doyle \& Glass, 2010) which is an important risk factor in cardiovascular disease. Therefore, international and national health organizations together with consumer organizations and the industry are advocating the reduction of sodium salt in food (Dötsch et al., 2009).

The WHO published new guidelines on the intake of sodium salt. In addition WHO now sets guidelines for the use of sodium salt, mineral salt and potassium salt by children for the first time, showing the importance of reduction of sodium intake (WHO, 2012). Sodium chloride salt is used as a traditional preservative in a variety of food products including many fermented products (Kilcast \& den Ridder, 2008). In sauerkraut, fermented white cabbage (Brassica oleracea), as much as $22.5 \mathrm{~g} \mathrm{~kg}^{-1} \mathrm{NaCl}$ may be used (Adams \& Moss, 1995). The amount used depends on fermentation temperature and market preference. However, in both the USA and the Netherlands, less $\mathrm{NaCl}$ (approximately15 $\mathrm{g} \mathrm{kg}^{-1}$ ) is used.

\footnotetext{
* Corresponding author. Tel.: +31 317 482887; fax: +31 317484978.

E-mail addresses: rob.nout@wur.nl, rob@ronfostec.nl (M.J.R. Nout).
}

Fermentation of sauerkraut involves natural microbiota, dominated by lactic acid bacteria that evolve in succession (Pederson, 1975). Gradually the fermenting microflora will be dominated by Leuconostoc mesenteroides, Lactobacillus plantarum, Lactobacillus sake, Lactobacillus brevis, and Lactobacillus curvatus (Nout \& Rombouts, 2000). Later studies have revealed an additional presence of among others, Lactobacillus paraplantarum, Lactobacillus coryniformis and Weissella sp. (Plengvidhya, Breidt, Lu, \& Fleming, 2007). Due to the activity of the lactic acid bacteria, the pH usually decreases to 3.4-3.7 (Plengvidhya et al., 2007). These acidic conditions allow the preservation of ascorbic acid, resulting in vitamin C contents of approximately $15 \mathrm{mg} 100 \mathrm{~g}^{-1}$ product (Singh, Upadhyay, Prasad, Bahadur, \& Rai, 2007).

$\mathrm{NaCl}$ in fermented cabbage has been ascribed several functions such as a preservative, inhibitor of endogenous pectolytic enzymes to prevent texture softening, and increasing the osmotic pressure that results in the extraction of the cabbage juice (Man, 2008). The latter contains substrates that are required for fermentation, and selective substances such as allyl-thiocyanates that inhibit undesirable Gram-negative bacteria. Cabbage juice also provides the liquid for submersion of the cabbage, thereby contributing to anaerobic conditions (Steinkraus, 1983).

An attempt to make salt-free sauerkraut was undertaken by Owades (1991), by replacing salt by an osmotically equivalent 
solution of ethanol and organic acids. Although some fermentation of cabbage was achieved, the process was unsuitable for producing commercially acceptable sauerkraut, especially regarding its texture and taste.

Viander, Mäki, and Palva (2003) and Wiander and Ryhänen (2005) showed that sauerkraut juice made at a low salt concentration of $5 \mathrm{~g} \mathrm{~kg}^{-1}$ of a mineral salt mixture (consisting of $57 \% \mathrm{NaCl}$, $28 \% \mathrm{KCl}, 12 \% \mathrm{MgSO}_{4}, 2 \%$ Lysine. $\mathrm{HCl}$, and $1 \% \mathrm{SiO}_{2}$ ) obtained a good sensory evaluation. However, low salt sauerkraut containing only about $5 \mathrm{~g} \mathrm{~kg}^{-1} \mathrm{NaCl}$, marketed in the Netherlands is mushy, i.e. lacks the desired crispy bite, and its taste is odd and needs to be masked by additives such as spices.

In addition, solely reducing salt content in fermented products such as sauerkraut could have consequences for food safety. As is well-known, $\mathrm{NaCl}$ has an important function in food preservation and safety (Doyle et al., 2010). Its ionic presence achieves a reduction of the water activity $\left(A_{w}\right)$. Recent outbreaks of Escherichia coli $\mathrm{O} 157$ food infections such as the one associated with salt preserved cabbage in Japan (Westlake, 2012), are facilitated in foods with a reduced salt content. Approaches with salt mixes of reduced Na-content may be helpful to combine the advantages of maintaining reduced $A_{w}$ for preservation and food safety, and of reducing $\mathrm{Na}$-intake by consumers.

In this study we aimed to study the effect of reduced sodium or reduced salt concentrations on the fermentation outcome and texture of sauerkraut, and investigate the possibilities to reduce $\mathrm{NaCl}$ while fulfilling commercial quality criteria. Our aim was to achieve a $40 \%$ reduction of sodium in sauerkraut and still obtain a crispy texture and normal fermentation outcomes, particularly microbiota, acidity, flavour, and vitamin $C$ retention. Since a simple lowering of the $\mathrm{NaCl}$ concentration results in lower osmotic pressure, we aimed at distinguishing the individual effects of reducing sodium, and of osmotic pressure. For that purpose we compared a $15 \mathrm{~g} \mathrm{~kg}^{-1} \mathrm{NaCl}$ control with a salt-reduced $\left(9 \mathrm{~g} \mathrm{~kg}^{-1} \mathrm{NaCl}\right)$ and a salt-replaced ( $15 \mathrm{~g} \mathrm{~kg}^{-1}$ mineral salts mixture giving approximately equal osmotic pressure as the control) fermentation.

\section{Materials and methods}

\subsection{Plant material}

White cabbage was obtained from Kramer and Sons B.V., ZuidScharwoude, the Netherlands. We used the variety "Atria", with a dense crop, popular for commercial sauerkraut making. Atria represents the largest harvests for sauerkraut. The cabbages were harvested in October, during the sauerkraut production season.

\subsection{Fermenter design}

Custom made fermentation vessels were used for sauerkraut production. These fermenters were made of non-transparent PVC measuring $1.5 \mathrm{~m}$ in height and $25 \mathrm{~cm}$ in diameter, similar as the design of Steinbuch (1971). A drainage port was located at $90 \mathrm{~cm}$ from the bottom. A stainless steel cylindrical sampling device $(2 \mathrm{~cm}$ diameter) was designed in a way to sample deep in the fermenter without disturbing the cabbage mass.

\subsection{Sauerkraut production}

Fresh cabbage was de-leafed and mechanically de-cored. Cabbage was cut into $1 \mathrm{~mm}$ thick shreds. Three pilot $100 \mathrm{~kg}$ scale fermentations were carried out in duplicate, [A] a control with $15 \mathrm{~g} \mathrm{~kg}^{-1} \mathrm{NaCl}$, [B] $40 \%$ sodium reduction by applying $9 \mathrm{~g} \mathrm{~kg}^{-1} \mathrm{NaCl}$, and [C] $40 \%$ sodium reduction by applying $15 \mathrm{~g} \mathrm{~kg}^{-1}$ of a saltreplacer mix -isotonic to the control- consisting of $9 \mathrm{~g} \mathrm{~kg}^{-1} \mathrm{NaCl}$,
$4.5 \mathrm{~g} \mathrm{~kg}^{-1} \mathrm{KCl}, 0.75 \mathrm{~g} \mathrm{~kg}^{-1} \mathrm{MgCl}_{2}$, and $0.75 \mathrm{~g} \mathrm{~kg}^{-1} \mathrm{CaCl}_{2}$. The rationale behind the composition of the salt replacer mixture is based on the salty taste of $\mathrm{KCl}$ and $\mathrm{CaCl}_{2}$, the favourable osmotic effect of $\mathrm{MgCl}_{2}$ and the firmness enhancing effect of $\mathrm{CaCl}_{2}$. Sauerkraut was fermented at ambient temperatures as practiced in the factory, at $12{ }^{\circ} \mathrm{C}$ during the first 6 weeks, followed by a storage period of 6 weeks at $9{ }^{\circ} \mathrm{C}$.

\subsection{Sampling}

Sampling during the fermentation period was done frequently at the start because significant changes occur, and less frequent towards the end when a stable situation is established. Samples were taken after 2, 4, 9, and 37 days. Consistency measurements and sensory analyses were done after 6 weeks i.e. end of fermentation, and after an additional storage period of 6 weeks i.e. 12 weeks in total. The latter sampling was done to simulate the delay between completion of fermentation and retailing.

\subsection{Microbiological analysis}

A $10 \mathrm{~g}$ sample was mixed with $90 \mathrm{ml}$ sterile PPS (peptone physiological saline, $1 \mathrm{~g} \mathrm{~L}^{-1}$ neutralized bacterial peptone and $8.5 \mathrm{~g} \mathrm{~L}^{-1} \mathrm{NaCl}$ ) in a sterile stomacher bag and homogenized (Stomacher ${ }^{\circledR} 400$ Circulator, Seward) at normal speed for $1 \mathrm{~min}$. The homogenate was then diluted with PPS and appropriate decimal dilutions were plated, either poured or spiral plated. Aerobic mesophilic micro-organisms were enumerated as Total Viable Count (TVC) using plate count agar (PCA, Oxoid CM0325), incubated at $30^{\circ} \mathrm{C}$ for $72 \mathrm{~h}$. Lactic Acid Bacteria (LAB) were enumerated in de Man, Rogosa and Sharpe (MRS) broth (Merck VM 986641) mixed with $15 \mathrm{~g} \mathrm{~L}^{-1}$ bacteriological agar (Oxoid LP0011), supplemented with $2 \mathrm{~g} \mathrm{~L}^{-1}$ Delvocid (50\% natamycin, DSM, the Netherlands). Plates were incubated under micro-aerobic conditions (air evacuated to 300 mbar with an Anaxomat WS9000, Mart, and filled with $80 \% \mathrm{~N}_{2}, 10 \% \mathrm{CO}_{2}$ and $10 \% \mathrm{H}_{2}$ gas mixture leaving a final concentration of $6 \% \mathrm{O}_{2}$ ) at $30{ }^{\circ} \mathrm{C}$ for $72 \mathrm{~h}$. Enterobacteriaceae were enumerated in pour plates of violet red bile glucose (VRBG) medium (Oxoid CM0485) with an overlay of the same medium and incubated at $37^{\circ} \mathrm{C}$ for $24 \mathrm{~h}$. Yeasts and moulds were enumerated on oxytetracycline glucose yeast extract (OGYE) agar (Oxoid CM0545B) supplemented with chloramphenicol supplement (Oxoid SR0078E) at $25{ }^{\circ} \mathrm{C}$ for 5 days.

\subsection{DNA extraction and PCR-DGGE}

Aliquots of $20 \mathrm{~g}$ of sauerkraut were mixed with $20 \mathrm{ml}$ distilled water and homogenized using an Ultra-Turrax ${ }^{\circledR}$ T25 basic (Ika ${ }^{\circledR}$ Werke). Total genomic DNA was extracted using a fast-DNA spin kit for soil (MP Biomedical) according to the manufacturer's instructions. Microbial genomic DNA isolated from sauerkraut was directly used to amplify the V6-V8 region of the bacterial 16S rRNA gene, using primers described by Nübel et al. (1996). PCR-DGGE was performed according to Lima et al. (2012).

\subsection{DNA clone library construction, sequencing and annotation of DGGE fingerprints}

Microbial genomic DNA isolated from different stages of fermentation was amplified with 16S rRNA gene universal primers. Clone libraries were made which were later used to annotate DGGE fingerprints, as described by Lima et al. (2012). A marker consisting of a mixture of amplicons obtained from the sauerkraut was included to facilitate gel normalization. Gels were silver stained according to the method of Sanguinetti, Neto, and Simpson (1994), 
and after overnight drying at $55^{\circ} \mathrm{C}$, the gel images were digitized on a GS 800 calibrated densitometer (Bio-Rad) and normalized using Bionumerics software v.4.0 (Applied Maths.) for data interpretation.

\subsection{Chemical analyses}

Titratable acidity was determined by titration with $4 \mathrm{~g} \mathrm{~L}^{-1} \mathrm{NaOH}$ of a homogenate of $10 \mathrm{~g}$ of sauerkraut in $25 \mathrm{ml}$ distilled water, prepared by Ultra-Turrax ${ }^{\circledR}$ T25 (Ika ${ }^{\circledR}$ Werke, Germany). Vitamin C content was determined on 1:5 dilutions of homogenates in $30 \mathrm{~g} \mathrm{~L} \mathrm{~L}^{-1}$ metaphosphoric acid (Merck 1.00546.0500) and $0.166 \mathrm{~g} \mathrm{~L}^{-1}$ tert-Butyl hydroquinone (Fluka 19986) in milliQ water. Diluted samples were filtered using a $13 \mathrm{~mm}$ HPLC Altech syringe Flt $0.45 \mu \mathrm{m}$ PTFE $100 \mathrm{pk}$ (BD Discardit syringe). HPLC, Ultimate 3000 (Dionex), using a Varian Polaris C18a $46 \times 150 \mathrm{~mm}$ column (Bio-Rad) with pre-column and single detection mode at $245 \mathrm{~nm}$ wavelength (UV absorption, Thermo Separation Products UV2000) was used for determination. Elution was with $20 \mathrm{~g} \mathrm{~L}^{-1}$ orthophosphoric acid at a flow rate of $1 \mathrm{ml} \mathrm{min}^{-1}$. Glucose, fructose, mannitol, ethanol, lactic acid and acetic acid were determined by HPLC as described earlier (Nyanga, Nout, Gadaga, Boekhout, \& Zwietering, 2008).

The presence of pectin methyl esterase (PME) was determined by a methyl red indicator method. $50 \mathrm{~g}$ of sauerkraut was homogenised using an Ultra-Turrax ${ }^{\circledR}$ T25 basic (Ika ${ }^{\circledR}$ Werke). After centrifugation (Heraus Instruments, Biofuge fresco) at 13,000 $\mathrm{g}$ for $5 \mathrm{~min}, 50 \mu \mathrm{l}$ of the supernatant was added to $5 \mathrm{ml}$ of pectin solution $\left(10 \mathrm{~g} \mathrm{~L}^{-1} \mathrm{HM}\right.$ pectin (Brown ribbon pectin)) in $8.78 \mathrm{~g} \mathrm{~L}^{-1}$ $\mathrm{NaCl}, 3$ drops of methyl red indicator, adjusted to $\mathrm{pH}$ 7.0. PME, when active on pectin decreases $\mathrm{pH}$, resulting in a colour change. Polygalacturonase activity (based on product formation) was determined on supernatant (as mentioned above) using HPAEC system, ICS3000 HPLC System (Dionex, Sunnyvale, USA) equipped with a CarboPac PA-1 column (Dionex, USA) in combination with a CarboPac PA guard column and an ICS3000 ED (Electrochemical Detector) (Dionex, USA). For elution, $4.0 \mathrm{~g} \mathrm{~L}^{-1} \mathrm{NaOH}$ and $82.03 \mathrm{~g} \mathrm{~L}^{-1} \mathrm{NaOAc}$ in $4.0 \mathrm{~g} \mathrm{~L}^{-1} \mathrm{NaOH}$ were used at a flow rate of $0.3 \mathrm{ml} \mathrm{min}{ }^{-1}$. Polygalacturonase activity (based on substrate degradation) was determined by HPSEC system, Ultimate 3000 (Dionex), using a TosoH Biosep TSKGel G2500 PWXL (Bio-Rad) with pre-column and detection by refractive index (Shodex RI 101). For elution, $17.0 \mathrm{~g} \mathrm{~L}^{-1} \mathrm{NaNO}_{3}$ was used at a flow rate of $0.6 \mathrm{ml} \mathrm{min}^{-1}$ at $40{ }^{\circ} \mathrm{C}$.

\subsection{Texture analysis}

The consistency of the cabbage was measured with a texture analyzer (Heavy Duty Platform (HDP/90)) and Miniature Kramer Shear/Ottawa Cell (HDP/MK05).

\subsection{Sensory evaluation}

Sauerkraut was evaluated after 6 and 12 weeks of fermentation. A taste panel of 5 trained persons evaluated the intensity attributes of various samples. The sauerkraut samples were evaluated for aroma, taste and texture. The samples were tasted in randomized order as blind tests. Prior to each random test, the mouth was rinsed with water. A score of $1-5$ was used for the sensory evaluation where number 1 refers to very bad and number 5 refers to excellent aroma, taste and texture.

\subsection{Statistics}

The least significant difference $(P \leq 0.05)$ test and the Student $t$ test $(P \leq 0.01)$ (Snedecor \& Cochran, 1980) were used to compare data.

\section{Results}

The numbers of total viable bacteria and lactic acid bacteria

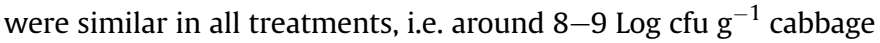
(Table 1). This indicates that the bacterial microbiota is dominated by lactic acid bacteria as could be expected. In all treatments the Enterobacteriaceae were detected at day 2 but from day 4 their presence could not be detected anymore. This phenomenon is in line with the relative sensitivity of Enterobacteriaceae for environmental stresses caused by the combination of salt and gradually increasing acidity. Yeasts and moulds were detected at low levels of 3.3-4.3 Log cfu $\mathrm{g}^{-1}$ only during the first few days of fermentation. After 9 day and later, numbers of yeasts and moulds were below the level of detection, i.e. $3.3 \mathrm{Log} \mathrm{cfu}^{-1}$.

Fig. 1 shows a representation of DGGE banding profiles of the three treatments after 2, 4, 9 and 37 days of fermentation. During the course of fermentation, we observed some shifts in microbiota composition. Leuc. mesenteroides and Lactococcus lactis ssp. lactis were present throughout. At 4 days of fermentation treatment B shows dominant presence of Leuc. mesenteroides and Lc. lactis ssp. lactis, while $\mathrm{A}$ and $\mathrm{C}$ show an additional presence of Kluyvera ascorbata, Lb. curvatus and Lb. coryniformis. At 9 days of fermentation, microbiota in $\mathrm{C}$ was more diverse than in $\mathrm{A}$ and $\mathrm{B}$ comprising $L b$. paraplantarum and $L b$. curvatus in addition to Leuc. mesenteroides and Lc. lactis ssp. lactis. Towards the final stage of fermentation predominant species were Lc. lactis ssp. lactis, Leuc. mesenteroides, $L b$. curvatus and Weissella cibaria. In all treatments, heterofermentative lactic acid bacteria were encountered but not quantified. We noticed that the microbiota at the final stage was still quite diverse and included at least 10 species.

Concentrations of glucose, fructose and sucrose in the juice of cabbage treatments during the fermentation are listed in Table 2. During the early stage (2 days) some differences were observed

Table 1

Microbiological composition during fermentation.

\begin{tabular}{|c|c|c|c|c|c|c|c|c|c|c|c|c|}
\hline & \multicolumn{3}{|c|}{ Total viable count } & \multicolumn{3}{|c|}{ Lactic acid bacteria } & \multicolumn{3}{|c|}{ Enterobacteriaceae } & \multicolumn{3}{|c|}{ Yeasts and moulds } \\
\hline & $A^{a}$ & B & $\mathrm{C}$ & A & B & $\mathrm{C}$ & A & B & $\mathrm{C}$ & A & B & $\mathrm{C}$ \\
\hline $2 \mathrm{~d}^{\mathrm{b}}$ & $8.7^{c}$ & 8.5 & 8.6 & 8.5 & 7.8 & 8.3 & 3.7 & 3.8 & 3.7 & 4.3 & 4.1 & 4.2 \\
\hline 4 & 8.6 & 8.1 & 8.5 & 8.5 & 8.4 & 8.4 & 3.4 & 3.5 & 3.3 & 4.4 & 3.3 & 3.3 \\
\hline 9 & 8.4 & 8.3 & 8.3 & 8.3 & 8.2 & 8.2 & $<3.3$ & $<3.3$ & $<3.3$ & $<3.3$ & 3.3 & $<3.3$ \\
\hline 37 & 7.6a & $8.0 \mathrm{~b}$ & 7.8ab & 8.1 & 8.0 & 8.2 & $<3.3$ & $<3.3$ & $<3.3$ & $<3.3$ & $<3.3$ & $<3.3$ \\
\hline
\end{tabular}

Arabics $(a-b)$ indicate significant difference $(P \leq 0.01)$ among means within the same row and microbial group.

a Treatment $\mathrm{A}$ : control $\mathrm{NaCl} 15 \mathrm{~g} \mathrm{~kg}^{-1}$ cabbage, treatment $\mathrm{B}$ reduced $\mathrm{NaCl} 9 \mathrm{~g} \mathrm{~kg}^{-1}$ cabbage, treatment $\mathrm{C}$ replacer mix $15 \mathrm{~g} \mathrm{~kg}^{-1}$ cabbage.

b Days of fermentation.

c Log CFU/g cabbage. 


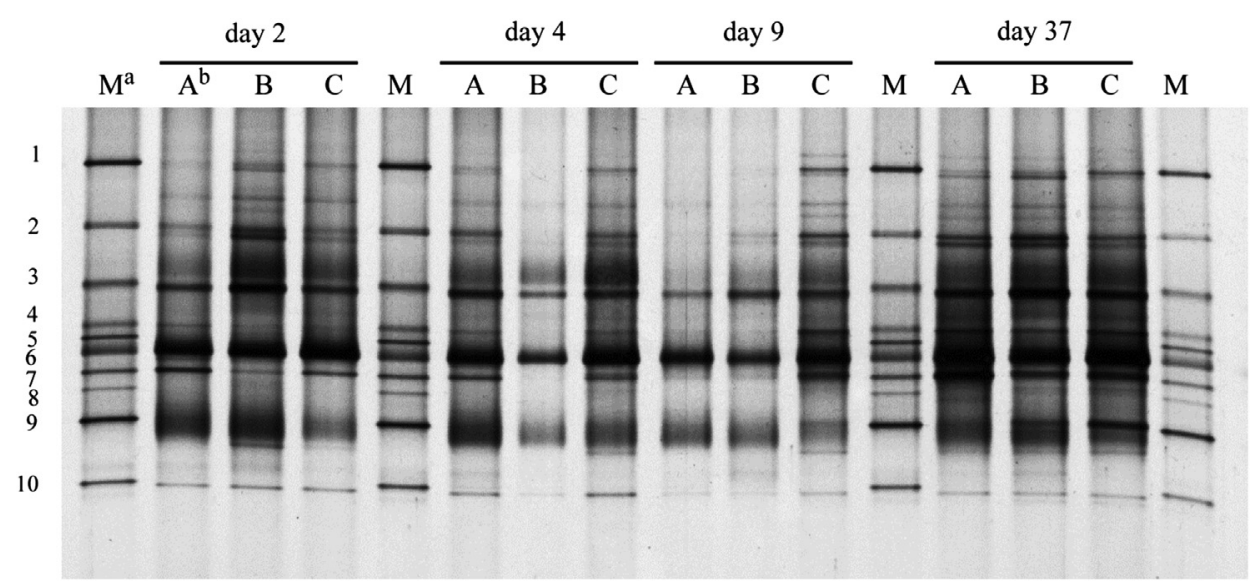

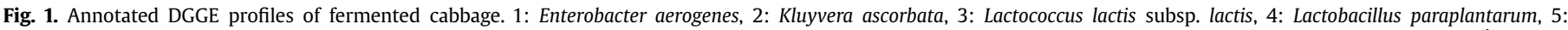

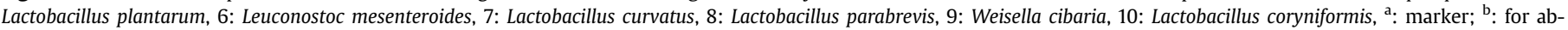
breviations see Table 1 .

between treatments, which levelled out during the time course of fermentation; overall during the fermentation, total sugars decreased but were not assimilated completely. It should be noted that these concentrations are the result of concomitant sugar extraction by salts from the cabbage, and their assimilation by microorganisms, and therefore are no direct index of either extraction efficiency or microbial activity. After 37 days of fermentation, treatment $C$ had a lower total sugar content than $A$ and $\mathrm{B}$ which were almost equal.

In Table 3, pH, titratable acidity, ethanol, acetic acid and lactic acid concentrations in cabbage during the fermentation are presented. In all treatments, the $\mathrm{pH}$ decreased rapidly to values $<4$, and the $\mathrm{pH}$ in final products was only slightly higher in treatment $\mathrm{B}$. Correspondingly, lactic acid concentrations increased with time in all treatments, to values $\leq 9.4 \mathrm{~g} \mathrm{~L}^{-1}$, with treatment B lagging a little behind compared to $A$ and $C$. Overall, in all treatments the majority of lactic acid was formed during the first few days of fermentation. In all 3 treatments an increase of ethanol concentrations from 9 to 37 days was observed; treatment $B$ had the lowest ethanol contents. Acetic acid levels were similar in all treatments.

Ascorbic acid contents of cabbage during the fermentation are summarized in Table 4, and were found to gradually increase to concentrations ranging from 19.6 to $32.7 \mathrm{mg} 100 \mathrm{~g}^{-1}$.

The activity of pectolytic enzymes was investigated in fresh cabbage, and in $23 \mathrm{~h}$ fermented cabbage. Pectin methyl esterase (PME) could not be detected in both samples (data not shown). In the fermented cabbage, the presence of exo-polygalacturonase (exo-PG) was established with equal activities of approximately $15 \mathrm{mU} / \mathrm{g}$ cabbage in all treatments A, B, and C. No signs of endo-PG activity such as pectin degradation products like oligomers of galacturonic acid, were detected in any of the treatments. We concluded that the salt treatments did not affect the activity of pectolytic enzymes differently.

Consistency measured by texturometer (Table 5) illustrates that fermented cabbage A after 6 weeks fermentation may become a little crispier during additional 6 weeks storage, whereas B and C tended to slightly loose crispiness after 12 weeks. Regardless of these within-treatment developments, there was a strong difference between the three treatments. Maximum force and surface area under the texturometer curve of cabbage $B$ (salt reduction) were considerably lower than those of $A$ and $C$.

Sensory evaluations of aroma, taste and texture are shown in Table 6. In this table, all data can be compared with each other. So in column 1 we see that B is significantly different from A and C, which are not different. The panel gave treatment B significantly lower scores for texture and taste. On the other hand, treatment $C$ was scored higher than $A$ for texture, expressed as crispiness. When comparing situations after 6 and 12 weeks, only in treatment B aroma and taste improved after storage. However, the resulting scores of treatment B were still low.

\section{Discussion}

All three treatments showed similar evolvement of groups of microorganisms. The fermentation was dominated by LAB, whereas Enterobacteriaceae, yeasts and moulds were not detectable anymore after a few days of fermentation. The fermentation vessels were well sealed despite the frequent samplings and there was no evidence of spoilage by oxidative yeasts (Fleming, McFeeters, Thompson, \& Sanders, 1983).

Some of the species encountered among the LAB were different than expected from previous reports (Nout \& Rombouts, 2000); in

Table 2

Sugars in the juice surrounding fermenting cabbage.

\begin{tabular}{|c|c|c|c|c|c|c|c|c|c|c|c|c|}
\hline \multirow[t]{2}{*}{ Fermentation } & \multicolumn{3}{|c|}{ Glucose } & \multicolumn{3}{|c|}{ Fructose } & \multicolumn{3}{|c|}{ Sucrose } & \multicolumn{3}{|c|}{ Total sugars } \\
\hline & $A^{a}$ & B & $\mathrm{C}$ & A & B & $\mathrm{C}$ & A & B & $\mathrm{C}$ & A & B & $\mathrm{C}$ \\
\hline $2 d^{a}$ & $17.3^{\mathrm{b}}$ & 11.2 & 15.3 & 24.1 & 16.7 & 22.0 & $1.4 \mathrm{a}$ & $0.5 b$ & $0.7 \mathrm{~b}$ & $42.8 \mathrm{a}$ & $28.4 \mathrm{c}$ & $38.0 \mathrm{~b}$ \\
\hline $4 \mathrm{~d}$ & 10.3 & 7.4 & 8.0 & 16.5 & 15.8 & 13.4 & 0.3 & 0.3 & 0.2 & $27.1 \mathrm{a}$ & $23.5 b$ & $21.6 c$ \\
\hline $9 \mathrm{~d}$ & $5.9 a$ & $5.4 \mathrm{ab}$ & $5.4 \mathrm{~b}$ & $10.6 a$ & $9.7 \mathrm{~b}$ & $9.7 b$ & 0.2 & 0.2 & 0.2 & $16.8 \mathrm{a}$ & $15.3 b$ & $15.3 b$ \\
\hline $37 \mathrm{~d}$ & 2.1 & 2.1 & 1.1 & 8.9ab & $8.8 \mathrm{a}$ & $7.7 \mathrm{~b}$ & $0.1 \mathrm{a}$ & $0.1 \mathrm{ab}$ & $0.1 \mathrm{~b}$ & $11.1 \mathrm{a}$ & $11.0 \mathrm{a}$ & $8.8 \mathrm{~b}$ \\
\hline
\end{tabular}

Arabics $(\mathrm{a}-\mathrm{c})$ indicate significant difference $(P \leq 0.01)$ among means within the same row and sugar.

a For abbreviations see Table 1 .

b $\mathrm{g} \mathrm{kg}^{-1}$ sauerkraut. 
Table 3

$\mathrm{pH}$, titratable acidity and concentrations of ethanol, acetic acid and lactic acid in fermenting cabbage.

\begin{tabular}{|c|c|c|c|c|c|c|c|c|c|c|c|c|c|c|c|}
\hline & \multicolumn{3}{|l|}{$\mathrm{pH}$} & \multicolumn{3}{|l|}{$\mathrm{TA}^{\mathrm{b}}$} & \multicolumn{3}{|c|}{ Ethanol $^{\mathrm{c}}$} & \multicolumn{3}{|c|}{ Acetic acidc $^{c}$} & \multicolumn{3}{|c|}{ Lactic acid ${ }^{c}$} \\
\hline & $A^{a}$ & B & $\mathrm{C}$ & A & B & $\mathrm{C}$ & A & B & $\mathrm{C}$ & A & B & $\mathrm{C}$ & A & B & $\mathrm{C}$ \\
\hline $2^{\mathrm{a}}$ & $4.5 a$ & 4.4ab & $4.3 b$ & 5.5 & 6.9 & 6.2 & 1.7 & 0.7 & 1.2 & 1.9 & 2.0 & 1.8 & 5.2 & 3.3 & 7.7 \\
\hline 4 & 4.1 & 4.1 & 4.0 & 7.8 & 7.9 & 9.5 & 1.5 & 1.2 & 1.1 & 1.9 & 2.0 & 1.8 & 8.6 & 8.4 & 7.1 \\
\hline 9 & 3.9 & 3.9 & 3.9 & 11.1 & 11.4 & 11.0 & 1.0 & 0.9 & 0.9 & 1.6 & 1.5 & 1.5 & 7.4 & 6.1 & 6.6 \\
\hline 37 & $3.6 b$ & $3.7 \mathrm{a}$ & $3.5 c$ & $15.0 \mathrm{a}$ & $13.0 \mathrm{~b}$ & $15.0 \mathrm{a}$ & 4.1 & 4.2 & 4.5 & 1.4 & 1.6 & 1.5 & 9.4 & 8.5 & 8.7 \\
\hline
\end{tabular}

Arabics $(a-c)$ indicate significant difference $(P \leq 0.01)$ among means within the same row and component.

a For abbreviations see Table 1.

b Expressed as $\mathrm{g} \mathrm{kg}^{-1}$ lactic acid.

c $\mathrm{g} \mathrm{kg}^{-1}$ sauerkraut.

particular, Lb. brevis, Lb. sake, Lb. bavaricus and Pediococcus spp. were not found. On the other hand, Lc. lactis ssp. lactis, Lb. coryniformis, $L b$. paraplantarum, $L b$. parabrevis, and $W$. cibaria were not reported before. Whereas Lc. lactis spp. lactis, Leuc. mesenteroides and $L b$. plantarum were predominant throughout, $L b$. coryniformis was observed in the early stages, and $L b$. paraplantarum, $L b$. parabrevis, and $W$. cibaria were observed at the end of the fermentation. We did not detect Pediococcus spp. as reported by Plengvidhya et al. (2007), but to the contrary we observed Lc. lactis and Lb. parabrevis. This may have been the result of different cabbage composition or fermentation temperatures used. We noticed that the microbiota at the final stage was still quite diverse and included at least 10 species. However, a consideration has to be made for the fact that our data are based on total DNA, and not RNA, so we could not confirm that all species detected at day 37 were still viable.

Within 9 days the pH decreased to below 4 in all treatments. This corresponds well with studies elsewhere on commercial sauerkraut (Plengvidhya et al., 2007; Pundir \& Jain, 2010; Trail, Fleming, Young, \& McFeeters, 1995) or naturally fermented cabbage at laboratory scale (Peñas, Frias, Sidro, \& Vidal-Valverde, 2010). All treatments achieved a final pH between 3.4 and 3.7. Apparently the acidification in treatment B was a little slower; this may have been related with a slower release of fermentable sugars as a result of lower osmotic pressure. In all cases some residual sugars remained as shown in Table 2 . The titratable acidity (TA) corresponds well with the decrease of $\mathrm{pH}$, and with data elsewhere (Trail et al., 1995). The acidity as well as the numbers of LAB evidence adequate and equal extent of lactic fermentation in all treatments. The sauerkraut contained higher levels of ethanol and acetic acid than published elsewhere (Trail et al., 1995), although Fleming and McFeeters (1984, pp. 25-29) also reported 0.55\% ethanol in European sauerkraut. As yeasts were almost absent, we ascribe these levels to the predominance of heterofermentative LAB.

The concentrations of ascorbic acid found after 37 days (19.6$32.7 \mathrm{mg} 100 \mathrm{~g}^{-1}$ ) are normal for fresh sauerkraut, fulfil German guidelines (Zipfel \& Rathke, 2008) and are about twice the value (14.7 mg $100 \mathrm{~g}^{-1}$ ) published for canned sauerkraut (USDA, 2009). The levels of measured ascorbic acid steadily increased and then stabilized during the fermentation, an increase that may be related

Table 4

Ascorbic acid in fermenting cabbage.

\begin{tabular}{llll}
\hline Days & $\mathrm{A}^{\mathrm{a}}$ & $\mathrm{B}$ & $\mathrm{C}$ \\
\hline 2 & $13.3^{\mathrm{b}}$ & 14.5 & 18.9 \\
4 & 11.4 & 14.6 & 12.9 \\
9 & 23.8 & 34.7 & 23.0 \\
37 & 32.7 & 32.0 & 19.6 \\
\hline a See Table 1. & & \\
b mg 100 g $^{-1}$ sauerkraut. & &
\end{tabular}

to the formation of ascorbigen (Martinez-Villaluenga et al., 2009), followed by its degradation in the acidic conditions (Wagner \& Rimbach, 2009). We did not analyze specifically for ascorbigen however.

An essential aspect of sauerkraut is its texture. As can be concluded from Table 5 , treatment $C$ has a considerable firmer texture than the salt reduced (B) and the control (A), which even presents an opportunity to lower the sodium content even more than we did in this experiment. The mineral salts mixture used in treatment $C$ maintains the osmotic pressure of the same order as control $\mathrm{A}$, and enables to retain a crispy texture.

The instrumental texture measurement corresponded very well with the texture scores given by the expert sensory panel, as shown in Table 6. Johanningsmeier, McFeeters, Fleming, and Thompson (2007) also noted that crispiness as determined by a sensory panel corresponded well with firmness as measured by objective instrumental methods. These authors reduced the $\mathrm{NaCl}$ content from 20 to $5 \mathrm{~g} \mathrm{~kg}^{-1}$ in a natural cabbage fermentation leading to a significant loss of firmness.

Our sensory panel also scored treatment B lower for taste. It is plausible that this lower appreciation is due to the unacceptable texture of sauerkraut treatment B.

Softening of cut vegetable tissue could result from different phenomena such as enzymic degradation of pectic substances, osmotic effects, or specific firming effects of divalent cations. The first option is unlikely since most pectic enzymes have temperature optima ranging between 45 and $55{ }^{\circ} \mathrm{C}$; since the sauerkraut fermentation was carried out at temperatures of approximately $12{ }^{\circ} \mathrm{C}$, the activity of these enzymes when present, would be impaired because of the sub-optimal temperature. This was confirmed by our unsuccessful attempts to detect activities of PME and PG. The second option (osmosis) is much more likely as evidenced from the loss of firmness when comparing control (A) and salt reduced (B) krauts. The explanation could be that higher osmotic forces extract more juice from the plant cells, making them firmer. The third option also seems to be of importance. McFeeters and Fleming (1989) observed the effect of lanthanide ions such as $\mathrm{Ca}^{++}$in inhibiting softening of brined cucumbers, although they

Table 5

Consistency by texturometer.

\begin{tabular}{llllll}
\hline \multirow{2}{*}{ Fermentation } & \multicolumn{2}{l}{ Maximum force $(\mathrm{N})$} & & \multicolumn{2}{l}{ Surface area $(\mathrm{N} \mathrm{s})$} \\
\cline { 2 - 3 } \cline { 6 - 6 } & $6^{\mathrm{a}}$ & & & 6 & 12 \\
\hline $\mathrm{A}^{\mathrm{b}}$ & $74 \mathrm{~b}$ & $98 \mathrm{c}$ & & $661 \mathrm{c}$ & $782 \mathrm{~d}$ \\
$\mathrm{~B}$ & $56 \mathrm{a}$ & $52 \mathrm{a}$ & & $504 \mathrm{~b}$ & $423 \mathrm{a}$ \\
$\mathrm{C}$ & $136 \mathrm{e}$ & $123 \mathrm{~d}$ & & $1228 \mathrm{f}$ & $1093 \mathrm{e}$ \\
\hline
\end{tabular}

Arabics $(a-f)$ indicate significant difference $(P \leq 0.01)$ among mean values of force and area, respectively.

a Weeks.

b Treatments, see Table 1. 
Table 6

Sensory evaluation of fermented cabbage.

\begin{tabular}{|c|c|c|c|c|c|c|}
\hline \multirow[t]{2}{*}{ Fermentation } & \multicolumn{2}{|l|}{ Aroma } & \multicolumn{2}{|l|}{ Taste } & \multicolumn{2}{|c|}{ Texture } \\
\hline & $6^{\mathrm{a}}$ & 12 & 6 & 12 & 6 & 12 \\
\hline$A^{b}$ & $3.4 \mathrm{bcd}$ & $3.2 \mathrm{bc}$ & $3.4 \mathrm{bc}$ & $3.6 c$ & $3.5 b$ & $3.8 \mathrm{bc}$ \\
\hline B & $2.0 \mathrm{a}$ & $3.0 \mathrm{~b}$ & $1.8 \mathrm{a}$ & $2.8 \mathrm{~b}$ & $2.2 \mathrm{a}$ & $2.4 a$ \\
\hline C & $3.5 \mathrm{bcd}$ & $3.7 \mathrm{~cd}$ & $3.7 \mathrm{c}$ & $3.8 \mathrm{c}$ & $4.4 c$ & $4.4 c$ \\
\hline
\end{tabular}

Arabics $(a-d)$ indicate significant difference $(P \leq 0.05)$ among all means.

a Weeks.

b Treatments, see Table 1.

could not explain this phenomenon on the basis of the "egg-box" effect. On a weight basis, the osmotic strength of $\mathrm{CaCl}_{2}$ is smaller than that of $\mathrm{NaCl}$, and therefore we only substituted $5 \%$ of the $\mathrm{NaCl}$ by $\mathrm{CaCl}_{2}$ in treatment $\mathrm{C}$.

In conclusion, simple $\mathrm{NaCl}$ reduction as in treatment B mainly has a negative effect on cabbage texture and leads to unacceptable sauerkraut. We conclude that the cabbage softening is not related to activities of pectolytic enzymes, but to the lower osmotic pressure resulting from the lower ionic concentration. The experimental treatment $\mathrm{C}$ with a mineral salts mixture of equal ionic concentration as the control was successful, as it enabled a similar fermentation outcome, and achieved even a slightly better crispiness, compared to the control A. As such, this treatment offers a technological option to produce high quality sauerkraut with a $40 \%$ reduced $\mathrm{Na}$ - content.

\section{Acknowledgements}

We gratefully acknowledge the contribution to the conceptual development by Gerrit Beldman, Wieteke Hendriksen, Bart Möller, Jelle Sijswerda, Sybren Sikkes, Rosalie Torensma, Ruben de Vries, and Sytze de Vries; we thank Kramer and Son, Zuid-Scharwoude, the Netherlands for on-site factory collaboration.

\section{References}

Adams, M. R., \& Moss, M. O. (Eds.). (1995). Food Microbiology. Cambridge, UK: The Royal Society of Chemistry.

Dötsch, M., Busch, J., Batenburg M., Liem, G., Tareilus, E., Müller, R., et al. (2009) Strategies to reduce sodium consumption: a food industry perspective. Critical Reviews in Food Science \& Nutrition, 49, 841-851.

Doyle, M. E., \& Glass, K. A. (2010). Sodium reduction and its effect on food safety, food quality, and human health. Comprehensive Reviews in Food Science and Food Safety, 9, 44-56

Fleming, H. P., \& McFeeters, R. F. (1984). Residual sugars and fermentation products in raw and finished commercial sauerkraut. In Sauerkraut seminar: Special Report 56.

Fleming, H. P., McFeeters, R. F., Thompson, R. L., \& Sanders, D. C. (1983). Storage stability of vegetables fermented with pH control. Journal of Food Science, 48, 975-981.

Johanningsmeier, S., McFeeters, R. F., Fleming, H. P., \& Thompson, R. L. (2007). Effects of Leuconostoc mesenteroides starter culture on fermentation of cabbage with reduced salt concentrations. Journal of Food Science, 72, M116-M172.

Kilcast, D., \& den Ridder, C. (2008). Sensory issues in reducing salt in food products. In D. Kilcast, \& F. Angus (Eds.), Reducing Salt in Foods (pp. 201-220). Cambridge: Woodhead.

Lima, L. J. R., van der Velpen, V., Wolkers-Rooijackers, J., Kamphuis, H. J., Zwietering, M. H., \& Nout, M. J. R. (2012). Microbiota dynamics and diversity at different stages of industrial processing of cocoa beans into cocoa powder. Applied E' Environmental Microbiology, 78, 2904-2913.

Man, C. M. B. (2008). Technological functions of salt in food products. In D. Kilcast, \& F. Angus (Eds.), Reducing Salt in Foods (pp. 157-173). Cambridge: Woodhead.

Martinez-Villaluenga, C., Peñas, E., Frias, J., Ciska, E., Honke, J., Piskula, M. K., et al. (2009). Influence of fermentation conditions on glucosinolates, ascorbigen, and ascorbic acid content in white cabbage (Brassica oleracea var. capitata cv. Taler) cultivated in different seasons. Journal of Food Science, 74, C62-C67.

McFeeters, R. F., \& Fleming, H. P. (1989). Inhibition of cucumber tissue softening in acid brines by multivalent cations: inadequacy of the pectin "egg box" model to explain textural effects. Journal of Agricultural \& Food Chemistry, 37, 1053-1059.

Nout, M. J. R., \& Rombouts, F. M. (2000). Fermented and acidified plant foods. In B. M. Lund, T. C. Baird-Parker, \& G. W. Gould (Eds.), The microbiological safety and quality of food (pp. 685-737). Gaithersburg, USA: Aspen Publishers.

Nübel, U., Engelen, B., Felske, A., Snaidr, J., Wieshuber, A., Amann, R. I., et al. (1996) Sequence heterogeneities of genes encoding 16S rRNAs in Paenibacillus polymyxa detected by temperature gradient gel electrophoresis. Journal of Bacteriology, 178, 5636-5643.

Nyanga, L. K., Nout, M. J. R., Gadaga, T. H., Boekhout, T., \& Zwietering, M. H. (2008) Traditional processing of Masau fruits (Ziziphus mauritiana) in Zimbabwe. Ecology of Food and Nutrition, 47, 95-107.

Owades, J. L. (1991). Method of making salt free sauerkraut. United States Patent 5.064.662.

Pederson, C. S. (1975). Microbiology of food fermentations. Westport CT: AVI Publ. Co., Inc.

Peñas, E., Frias, J., Sidro, B., \& Vidal-Valverde, C. (2010). Chemical evaluation and sensory quality of sauerkrauts obtained by natural and induced fermentations at different $\mathrm{NaCl}$ levels from Brassica oleracea var. capitata $\mathrm{Cv}$. Bronco grown in eastern Spain. Effect of storage. Journal of Agricultural $\mathcal{E}$ Food Chemistry, 58 3549-3557.

Plengvidhya, V., Breidt, F., Lu, Z., \& Fleming, H. P. (2007). DNA fingerprinting of lactic acid bacteria in sauerkraut fermentations. Applied E Environmental Microbiology, 73, 7697-7702.

Pundir, R. K. \& Jain, P. (2010). Change in microflora of sauerkraut during fermentation and storage. World Journal of Dairy \& Food Sciences, 5, 221-225.

Sanguinetti, C. J., Neto, E. D., \& Simpson, A. J. G. (1994). Rapid silver staining and recovery of PCR products separated on polyacrylamide gels. Biotechniques, 17, 915-919.

Singh, J., Upadhyay, A. K., Prasad, K., Bahadur, A., \& Rai, M. (2007). Variability of carotenes, vitamin C, E and phenolics in Brassica vegetables. Journal of Food Composition \&' Analysis, 20, 106-112.

Snedecor, G. W., \& Cochran, W. G. (1980). Statistical Methods. Ames, Iowa, USA: The Iowa State University Press.

Steinbuch, E. (1971). Verfärbungen von Sauerkraut infolge Fermentationsschwierigkeiten. Die Industrielle Obst- und Gemüseverwertung, 56, 311-315.

Steinkraus, K. H. (1983). Lactic acid fermentation in the production of foods from vegetables, cereals and legumes. Antonie Van Leeuwenhoek, 49, 337-348.

Trail, A. C. Fleming, H. P. Young, C. T., \& McFeeters, R. F. (1995). Chemical and sensory characterization of commercial sauerkraut. Journal of Food Quality, 19, 15-30.

USDA. (2009). Sauerkraut, canned, solids and liquids. http://www.nal.usda.gov/fnic/ foodcomp/cgi-bin/list_nut_edit.pl.

Viander, B., Mäki, M., \& Palva, A. (2003). Impact of low salt concentration, salt quality on natural large-scale sauerkraut fermentation. Food Microbiology, 20 391-395.

Wagner, A. E., \& Rimbach, G. (2009). Ascorbigen: chemistry, occurrence, and biologic properties. Clinics in Dermatology, 27, 217-224.

Westlake, A. (16 Sept 2012). E. coli contaminated pickled cabbage kills 7, injures over 100. Japan Daily Press.

WHO. (2012). Guideline: Sodium intake for adults and children. Geneva: World Health Organisation.

Wiander, B., \& Ryhänen, E.-L. (2005). Laboratory and large-scale fermentation of white cabbage into sauerkraut and sauerkraut juice by using starters in combination with mineral salt with a low $\mathrm{NaCl}$ content. European Food Research $\mathcal{E}$ Technology, 220, 191-195.

Zipfel, W., \& Rathke, K.-D. (2008). 319. Richtlinie für die Herstellung, Beurteilung und Kennzeichnung von Sauerkraut. Lebensmittelrecht, 134. Ergänzungslieferung. München: Beck http://beckonline.beck.de/default.aspx?vpath=bibdata\%2Fkom m\%2FZipRathKoLMR\%5F134\%2FBuch\%2Fcont\%2FZipRathKoLMR\%2Ehtm. 